\title{
Community structure and carbon and nitrogen storage of sagebrush desert under grazing exclusion in Northwest China
}

\author{
DONG Yiqiang $^{1,2,3}$, SUN Zongjiu ${ }^{1,2}$, AN Shazhou ${ }^{1,2 *}$, JIANG Shasha ${ }^{1}$, WEI Peng ${ }^{1}$ \\ ${ }^{1}$ College of Pratacultural and Environmental Science, Xinjiang Agricultural University, Urumqi 830052, China; \\ ${ }^{2}$ Key Laboratory of Grassland Resources and Ecology of Xinjiang, Urumqi 830052, China; \\ ${ }^{3}$ Post-doctoral Mobile Station of Xinjiang Agricultural University, Urumqi 830052, China
}

\begin{abstract}
Overgrazing is regarded as one of the key factors of vegetation and soil degradation in the arid and semi-arid regions of Northwest China. Grazing exclusion (GE) is one of the most common pathways used to restore degraded grasslands and to improve their ecosystem services. Nevertheless, there are still significant controversies concerning GE's effects on grassland diversity as well as carbon (C) and nitrogen (N) storage. It remains poorly understood in the arid desert regions, whilst being essential for the sustainable use of grassland resources. To assess the effects of GE on community characteristics and C and $\mathrm{N}$ storage of desert plant community in the arid desert regions, we investigated the community structure and plant biomass, as well as $\mathrm{C}$ and $\mathrm{N}$ storage of plants and soil $(0-100 \mathrm{~cm}$ depth) in short-term GE (three years) plots and adjacent long-term freely grazing (FG) plots in the areas of sagebrush desert in Northwest China, which are important both for spring-autumn seasonal pasture and for ecological conservation. Our findings indicated that GE was beneficial to the average height, coverage and aboveground biomass (including stems, leaves and inflorescences, and litter) of desert plant community, to the species richness and importance values of subshrubs and perennial herbs, and to the biomass $\mathrm{C}$ and $\mathrm{N}$ storage of aboveground parts $(P<0.05)$. However, GE was not beneficial to the importance values of annual herbs, root/shoot ratio and total $\mathrm{N}$ concentration in the $0-5$ and $5-10 \mathrm{~cm}$ soil layers $(P<0.05)$. Additionally, the plant density, belowground biomass, and soil organic $\mathrm{C}$ concentration and $\mathrm{C}$ storage in the $0-100 \mathrm{~cm}$ soil layer could not be significantly changed by short-term GE (three years). The results suggest that, although GE was not beneficial for $\mathrm{C}$ sequestration in the sagebrush desert ecosystem, it is an effective strategy for improving productivity, diversity, and $\mathrm{C}$ and $\mathrm{N}$ storage of plants. As a result, GE can be used to rehabilitate degraded grasslands in the arid desert regions of Northwest China.
\end{abstract}

Keywords: grazing exclusion; desert plant community; biomass; C storage; $\mathrm{N}$ storage; fencing; arid desert regions

Citation: DONG Yiqiang, SUN Zongjiu, AN Shazhou, JIANG Shasha, WEI Peng. 2020. Community structure and carbon and nitrogen storage of sagebrush desert under grazing exclusion in Northwest China. Journal of Arid Land, 12(2): 239-251. https://doi.org/10.1007/s40333-020-0123-5

\section{Introduction}

Grassland ecosystems are primarily distributed in both the arid and semi-arid regions, and occupy more than $30 \%$ of the global land surface (Shi et al., 2014). They play an essential role in maintaining the balance between primary productivity and herbivores (Feng et al., 2010). As well

\footnotetext{
*Corresponding author: AN Shazhou (E-mail: xjasz@126.com)

Received 2018-04-27; revised 2019-06-04; accepted 2019-09-12

C Xinjiang Institute of Ecology and Geography, Chinese Academy of Sciences, Science Press and Springer-Verlag GmbH Germany, part of Springer Nature 2020
} 
as primary productivity, they provide substantial additional ecosystem functions, such as diversity maintenance, soil and water protection, and carbon $(\mathrm{C})$ and nitrogen $(\mathrm{N})$ sequestration (Zhang et al., 2015; Ebrahimi et al., 2016; Fu and Shen, 2017; Fu et al., 2018). The main method of grassland utilization worldwide is grazing (Dong et al., 2011), which can alter community structure and affect $\mathrm{C}$ and $\mathrm{N}$ storage (Mcsherry and Ritchie, 2013; Sigcha et al., 2018). Continuous overgrazing and poor management could induce severe grassland degradation and pose an increasing threat to ecosystem functioning and biodiversity (Shao et al., 2016). Dramatic degradation of grassland significantly reduces primary productivity and simultaneously causes substantial ecological problems, such as biodiversity loss and reduction of $\mathrm{C}$ sequestration capacity (El-Keblawy, 2017). The worsening degradation has led to various efforts being implemented around the world that aim to eliminate the negative effect of overgrazing, such as excluding grazers, reseeding and changing land use practices. A common approach to stimulate self-recovery is by grazing exclusion (GE), which is now widely viewed as one of the most efficient ways to reverse grassland degradation (Bi et al., 2018; Wang et al., 2018).

In previous studies, the effects of GE on plant community characteristics, soil organic carbon (SOC) and soil total nitrogen (STN) stocks have not been conclusive, and there remains considerable uncertainty about the effects of GE on biomass $\mathrm{C}$ and $\mathrm{N}$ allocations (Hu et al., 2016; Bi et al., 2018). With respect to productivity, some studies have found that there were no significant differences in plant biomass between freely grazing (FG) and GE regions (Fu et al., 2014; Dong et al., 2017), whereas others showed that GE markedly restored vegetation and enhanced productivity of degraded grasslands (Wu et al., 2009; Jing et al., 2014; Wang et al., 2018). Additionally, some research has indicated that GE was conducive to the maintenance of plant species diversity (Zhao and Gillet, 2011; Mekuria and Aynekulu, 2013; Zhang and Zhao, 2015), whereas others reported no change and even a decrease of species diversity, due to litter accumulation altering access to light, water and competitive exclusion of species (Wu et al., 2009; Bi et al., 2018; Sigcha et al., 2018). Similarly, the effects of GE on soil nutrients are controversial. For instance, GE produces diverse results on SOC, with evidence of positive (Wu et al., 2010; Qiu et al., 2013; Li et al., 2014), negative (Lu et al., 2015; Bi et al., 2018) or neutral (Dong et al., 2012) effects. Hu et al. (2016) reported that 299 out of a total 326 (i.e., 92\%) measurements with GE showed increases of SOC storage in China. Additionally, GE is mainly concentrated in vulnerable areas of North and Southwest China, especially in the semi-arid grasslands of Inner Mongolia Plateau (Wu et al., 2014) and Qinghai-Tibetan Plateau (Wu et al., 2015). Nevertheless, the effects of GE on grassland community structure and functioning in the arid desert regions of Northwest China remain poorly studied, especially in the sagebrush desert. Therefore, it is important to understanding the responses of the essential characteristics of desert ecosystems to GE.

Sagebrush desert covers more than $4 \%$ of the desert region in Xinjiang Uygur Autonomous Region of Northwest China. It is a vital spring-autumn seasonal pasture and plays an important foundation for the development of local animal husbandry (Dong et al., 2017). However, the dramatic degradation of the desert in relation to human disturbance and extreme drought causes a series of ecological problems that hinder the growth of vegetation. GE is a common approach to restoring the degraded sagebrush desert. In this study, we compared the desert plant community structure and productivity, as well as $\mathrm{C}$ and $\mathrm{N}$ storage in plants and soil in the sagebrush desert of Xinjiang under FG and GE conditions. The specific objectives of the study were (1) to investigate the effects of GE on vegetation community structure, productivity, and $\mathrm{C}$ and $\mathrm{N}$ storage; and (2) to evaluate the responses of SOC and STN concentrations and storage characteristics to GE. The results can be used as a basis for grassland restoration and scientific management in the arid desert regions of China as well as other similar areas in the world.

\section{Materials and methods}

\subsection{Study area}

This study was conducted in Manas County $\left(44^{\circ} 01^{\prime} \mathrm{N}, 86^{\circ} 09^{\prime} \mathrm{E}\right.$; $1033 \mathrm{~m}$ a.s.1.) and Hutubi County 
$\left(43^{\circ} 58^{\prime} \mathrm{N}, 86^{\circ} 32^{\prime} \mathrm{E} ; 978 \mathrm{~m}\right.$ a.s.1.), which are both representative of sagebrush desert in Xinjiang of Northwest China. The study area extends from the north of the Tianshan Mountains to the south of the Junggar Basin. It has a typical temperate continental arid climate characterized by short, hot summers and long, cold winters with harsh environment and extremely fragile ecosystems (Dong et al., 2017). The mean annual precipitation (MAP) is about $150-250 \mathrm{~mm}$, of which approximately $60 \%$ falls from April to August. The annual mean temperature (AMT) is about $6.0^{\circ} \mathrm{C}-8.0^{\circ} \mathrm{C}$. The soil type is belonging to gray desert soil according to the FAO/UNESCO taxonomy.

Sagebrush desert regions in Manas County and Hutubi County had similar plant species composition and land use history. They were employed as the spring-autumn pasture and grazed by sheep at a moderate grazing intensity $\left(0.6-1.0\right.$ sheep $\left./ \mathrm{hm}^{2}\right)$ before GE (Dong et al., 2016). Seriphidium transiliense is a dominant constructive species in the studied sagebrush desert regions, while the companion species include Petrosimonia sibirica, Carex turkestanica, Kochia prostrata, Ceratocarpus arenarius and Salsola collina.

\subsection{Experimental design}

In 2015, we established two experimental sites in the sagebrush desert regions of Manas County and Hutubi County, which were abbreviated as MNS and HTB, respectively. The details of the two sites are shown in Table 1. At each site, one paired short-term GE plot and adjacent long-term FG plot were selected. Livestock were completely excluded from the GE plots of MNS and HTB with metal fences, and the FG plots were grazed by sheep in spring and autumn. The desert plant community composition and structure, topographic features and other environmental conditions in the GE plots are basically consistent with the FG plots in both MNS and HTB, and the terrain is flat in all plots.

Table 1 Summary conditions of the experimental sites

\begin{tabular}{|c|c|c|c|c|c|c|}
\hline Experimental site & Plot & Dominant species & Location & Altitude (m) & $\operatorname{AMT}\left({ }^{\circ} \mathrm{C}\right)$ & $\operatorname{MAP}(\mathrm{mm})$ \\
\hline MNS & $\begin{array}{l}\text { FG } \\
\text { GE }\end{array}$ & $\begin{array}{c}\text { Seriphidium transiliense, } \\
\text { Petrosimonia sibirica } \\
\text { S. transiliense, } \\
\text { Carex turkestanica }\end{array}$ & $44^{\circ} 01^{\prime} \mathrm{N}, 86^{\circ} 09^{\prime} \mathrm{E}$ & 1033 & 8.18 & 172 \\
\hline HTB & $\begin{array}{l}\text { FG } \\
\text { GE }\end{array}$ & $\begin{array}{c}\text { S. transiliense, } \\
\text { P. sibirica } \\
\text { S. transiliense, } \\
\text { C. turkestanica }\end{array}$ & $43^{\circ} 58^{\prime} \mathrm{N}, 86^{\circ} 32^{\prime} \mathrm{E}$ & 978 & 6.79 & 224 \\
\hline
\end{tabular}

Note: MNS, experiment site in the sagebrush desert region of Manas County; HTB, experiment site in the sagebrush desert region of Hutubi County; FG, freely grazing; GE, grazing exclusion; AMT, annual mean temperature; MAP, mean annual precipitation.

\subsection{Field sampling and laboratory analysis}

Vegetation measurements and soil sampling were conducted in late September 2017, which was a typical period of peak aboveground biomass (AGB). In each plot, three random sampling transects were chosen at $100 \mathrm{~m}$ intervals, then five sampling quadrats $(1 \mathrm{~m} \times 1 \mathrm{~m})$ at $10 \mathrm{~m}$ intervals along each transect were established. In all 60 quadrats $(2$ sites $\times 2$ plots $\times 3$ transects $\times 5$ quadrats $)$, the plant species were identified and recorded, followed by the measurements of the height, coverage and number of each species. The aboveground parts and surface litter were harvested, and then the stems, leaves and inflorescences were removed from the whole plant and placed in separate envelopes. To measure the belowground biomass (BGB), we collected soil samples at 0 $100 \mathrm{~cm}$ depth by digging a soil profile in each transect. Roots in the composite soil samples were collected by washing the soil using a $2-\mathrm{mm}$ sieve. Then, the aboveground parts (stems, leaves and inflorescences, and litter) and belowground parts of all plants were weighted after drying at $80^{\circ} \mathrm{C}$ to a constant weight. All plant species were divided into three different functional groups: subshrubs, perennial herbs and annual herbs.

Three representative soil profiles were dug along a diagonal direction in each plot. Soil bulk density was measured by using soil cores $\left(100 \mathrm{~cm}^{3}\right.$ volume; $5.1 \mathrm{~cm}$ high and $5.0 \mathrm{~cm}$ in diameter) at seven depths $(0-5,5-10,10-20,20-30,30-50,50-70$ and $70-100 \mathrm{~cm})$ in three sides of each profile. Similarly, soil samples were obtained by spade from the same seven depths in three sides 
of each profile, then the soil samples from the same layers of each profile were mixed. This produced a more representative set of 84 samples $(2$ sites $\times 2$ plots $\times 3$ profiles $\times 7$ soil layers $)$, which were used to evaluate the mass of SOC and STN. All soil samples were air-dried at room temperature after removing the fresh roots and other plant residues, then hand-sieved through a 0.25-mm sieve after grinding (Wu et al., 2014; Bi et al., 2018).

In the laboratory, plant $\mathrm{C}$ and SOC concentrations were determined using the Walkley-Black dichromate oxidation method, and plant $\mathrm{N}$ and STN concentrations were determined using the indophenol blue colorimetry and nesslerization methods, respectively (Bao, 2000).

\subsection{Data analysis}

\subsubsection{Plant and soil parameters}

The plant species diversity was described by the Patrick richness index $(R)$, the Shannon-Wiener diversity index $(H)$ and the Pielou evenness index $(E)$ (Wu et al., 2009), which were calculated by the following formulas:

$\mathrm{IV}=($ relative height + relative coverage + relative density + relative biomass $) / 4$,

$$
\begin{gathered}
R=S, \\
H=-\sum P_{i} \ln P_{i}, \\
E=H / \ln S,
\end{gathered}
$$

where IV is the importance value of a species; $S$ is the number of species in the community; and $P_{i}$ is a representation of the importance value of the $i^{\text {th }}$ species.

Plant C storage $\left(\mathrm{g} / \mathrm{m}^{2}\right)$ and $\mathrm{N}$ storage $\left(\mathrm{g} / \mathrm{m}^{2}\right)$ were calculated according to the method of Fang et al. (2007) as follows:

$$
\begin{aligned}
& \text { C storage }=\sum\left(\mathrm{BC}_{i} \times \text { Biomass }_{i} \times 10^{-3}\right), \\
& \mathrm{N} \text { storage }=\sum\left(\mathrm{BN}_{i} \times \text { Biomass }_{i} \times 10^{-3}\right),
\end{aligned}
$$

where $\mathrm{BC}_{i}$ and $\mathrm{BN}_{i}$ are the $\mathrm{C}$ and $\mathrm{N}$ concentrations of the $i^{\text {th }}$ component of plant species $(\mathrm{g} / \mathrm{kg})$, respectively; and Biomass ${ }_{i}$ is the biomass of the $i^{\text {th }}$ component of plant species $(\mathrm{g})$.

We calculated SOC storage $\left(\mathrm{g} / \mathrm{m}^{2}\right)$ and STN storage $\left(\mathrm{g} / \mathrm{m}^{2}\right)$ according to the method of Shrestha and Stahl (2008) as follows:

$$
\begin{aligned}
& \text { SOC storage }=\sum_{i=1}^{7} \mathrm{SOC}_{i} \times \mathrm{BD}_{i} \times(1-\theta \%) \times H_{i} \times 10^{-3}, \\
& \text { STN storage }=\sum_{i=1}^{7} \mathrm{STN}_{i} \times \mathrm{BD}_{i} \times(1-\theta \%) \times H_{i} \times 10^{-3},
\end{aligned}
$$

where $\mathrm{SOC}_{i}$ and $\mathrm{STN}_{i}$ are the $\mathrm{SOC}$ and $\mathrm{STN}$ concentrations in different soil layers $(\mathrm{g} / \mathrm{kg})$, respectively; and $\mathrm{BD}_{i}, H_{i}$ and $\theta \%$ are the bulk density $\left(\mathrm{g} / \mathrm{cm}^{3}\right)$, the thickness of the $i^{\text {th }}(i=1,2,3,4$, 5,6 and 7) soil layer $(\mathrm{cm})$ and the percentage of rock fragments ( $>2 \mathrm{~mm}$ diameter), respectively.

2.4.2 Statistical analyses

Analysis of all the data was performed with the SPSS 20.0 software (IBM, Chicago, IL, USA) and Sigmaplot 10.0 (SYSTAT, California, San Jose, USA). After a normal distribution test for all the data, we performed a paired-sample $t$-test to identify significant differences of community characteristics, plant diversity indices, $\mathrm{C}$ and $\mathrm{N}$ storage of plants (stems, leaves and inflorescences, litter and root) and soil (0-100 cm depth) between GE and FG plots, therefore assessed the effects of GE on vegetation and soil properties. Evaluation of the significance for all the statistical tests was carried out at $P=0.05$ level.

\section{Results}

\subsection{Plant community structure}

Changes in plant community structure in the sagebrush desert regions are shown in Table 2. In the GE plots, the average vegetation heights in MNS and HTB were 12.75 and $29.10 \mathrm{~cm}$ higher 
$(P<0.05)$ than those in the FG plots, respectively; and the total vegetation coverage values were $31.78 \%$ and $60.56 \%$ higher $(P<0.05)$ than those in the FG plots, respectively. A significant difference in the diversity index was found in MNS and in the richness index in HTB, indicating that GE increased the biodiversity of sagebrush desert. However, GE did not significantly affect the total density of plant species $(P>0.05)$. There were also no significant differences in the richness index between FG and GE plots in MNS, the diversity index in HTB, and the evenness index in both MNS and HTB.

Table 2 Desert plant community structure characteristics in the FG and GE plots in MNS and HTB

\begin{tabular}{|c|c|c|c|c|c|c|c|}
\hline Experimental site & Plot & $\begin{array}{l}\text { Average height } \\
(\mathrm{cm})\end{array}$ & $\begin{array}{c}\text { Total coverage } \\
(\%)\end{array}$ & $\begin{array}{l}\text { Total density } \\
\left(\text { plants } / \mathrm{m}^{2}\right)\end{array}$ & $\begin{array}{c}\text { Richness } \\
\text { index }\end{array}$ & $\begin{array}{c}\text { Diversity } \\
\text { index }\end{array}$ & $\begin{array}{c}\text { Evenness } \\
\text { index }\end{array}$ \\
\hline \multirow{2}{*}{ MNS } & FG & $18.41 \pm 1.10^{\mathrm{b}}$ & $29.22 \pm 2.48^{b}$ & $93.11 \pm 43.70^{\mathrm{a}}$ & $2.44 \pm 0.18^{\mathrm{a}}$ & $0.53 \pm 0.07^{b}$ & $0.61 \pm 0.08^{\mathrm{a}}$ \\
\hline & GE & $31.16 \pm 3.29^{\mathrm{a}}$ & $61.00 \pm 4.26^{\mathrm{a}}$ & $82.33 \pm 25.63^{\mathrm{a}}$ & $2.67 \pm 0.53^{\mathrm{a}}$ & $0.85 \pm 0.10^{\mathrm{a}}$ & $0.82 \pm 0.04^{\mathrm{a}}$ \\
\hline \multirow{2}{*}{ НТВ } & $\mathrm{FG}$ & $11.04 \pm 1.05^{\mathrm{b}}$ & $21.33 \pm 1.95^{\mathrm{b}}$ & $98.78 \pm 33.29^{\mathrm{a}}$ & $1.56 \pm 0.18^{\mathrm{b}}$ & $0.44 \pm 0.06^{\mathrm{a}}$ & $0.63 \pm 0.08^{\mathrm{a}}$ \\
\hline & GE & $40.14 \pm 3.94^{\mathrm{a}}$ & $81.89 \pm 21.43^{\mathrm{a}}$ & $58.78 \pm 13.19^{\mathrm{a}}$ & $2.78 \pm 1.20^{\mathrm{a}}$ & $0.70 \pm 0.11^{\mathrm{a}}$ & $0.65 \pm 0.04^{\mathrm{a}}$ \\
\hline
\end{tabular}

Note: Different lowercase letters mean significant difference between FG and GE plots at $P<0.05$ level. Mean \pm SE.

In MNS and HTB, the average plant height, coverage, density and importance values of different functional groups in the GE and FG plots are shown in Table 3. In MNS, the average plant height and coverage of subshrubs in the GE plot were significantly greater (1.39 and 2.21 times, respectively) than those in the FG plot $(P<0.05)$. GE significantly increased the importance values of perennial herbs, whereas it decreased the importance values of annual herbs. Similarly, in HTB, the plant height, coverage, density and importance values of subshrubs in the GE plot were $2.11,4.41,1.83$ and 1.19 times larger than those in the FG plot $(P<0.05)$, respectively. Simultaneously, GE significantly increased the importance values of perennial herbs, whereas annual herbs disappeared after GE.

Table 3 Average plant height, coverage, density and importance values of different function groups in the FG and GE plots in MNS and HTB

\begin{tabular}{|c|c|c|c|c|c|}
\hline Experimental site & Index & Plot & Subshrubs & Perennial herbs & Annual herbs \\
\hline \multirow{8}{*}{ MNS } & \multirow{2}{*}{ Average height $(\mathrm{cm})$} & $\mathrm{FG}$ & $30.54 \pm 2.49^{b}$ & $1.57 \pm 1.06^{\mathrm{b}}$ & $6.39 \pm 1.33^{\mathrm{a}}$ \\
\hline & & $\mathrm{GE}$ & $42.44 \pm 3.66^{\mathrm{a}}$ & $5.20 \pm 1.37^{\mathrm{a}}$ & $6.22 \pm 2.22^{\mathrm{a}}$ \\
\hline & \multirow{2}{*}{ Coverage $(\%)$} & FG & $23.47 \pm 3.07^{\mathrm{b}}$ & $0.28 \pm 0.19^{b}$ & $4.33 \pm 2.23^{\mathrm{a}}$ \\
\hline & & $\mathrm{GE}$ & $51.78 \pm 4.43^{\mathrm{a}}$ & $8.44 \pm 3.31^{\mathrm{a}}$ & $0.78 \pm 0.01^{\mathrm{b}}$ \\
\hline & \multirow{2}{*}{ Density (plants $/ \mathrm{m}^{2}$ ) } & FG & $26.17 \pm 2.41^{\mathrm{a}}$ & $2.33 \pm 1.98^{\mathrm{b}}$ & $63 \pm 4.11^{\mathrm{a}}$ \\
\hline & & $\mathrm{GE}$ & $21.78 \pm 2.09^{\mathrm{a}}$ & $59.67 \pm 6.60^{\mathrm{a}}$ & $0.89 \pm 0.02^{\mathrm{b}}$ \\
\hline & \multirow{2}{*}{ Importance value } & FG & $0.74 \pm 0.06^{\mathrm{a}}$ & $0.08 \pm 0.02^{\mathrm{b}}$ & $0.18 \pm 0.06^{\mathrm{a}}$ \\
\hline & & GE & $0.78 \pm 0.06^{\mathrm{a}}$ & $0.19 \pm 0.06^{\mathrm{a}}$ & $0.03 \pm 0.02^{\mathrm{b}}$ \\
\hline \multirow{8}{*}{ НTB } & \multirow{2}{*}{ Average height $(\mathrm{cm})$} & FG & $20.71 \pm 1.53^{b}$ & $0.70 \pm 0.47^{\mathrm{b}}$ & $3.11 \pm 0.75$ \\
\hline & & GE & $43.76 \pm 2.12^{\mathrm{a}}$ & $16.83 \pm 8.41^{\mathrm{a}}$ & - \\
\hline & \multirow{2}{*}{ Coverage $(\%)$} & FG & $18.00 \pm 1.53^{\mathrm{b}}$ & $0.33 \pm 0.24^{\mathrm{b}}$ & $2.78 \pm 0.69$ \\
\hline & & GE & $79.44 \pm 1.94^{\mathrm{a}}$ & $2.44 \pm 1.12^{\mathrm{a}}$ & - \\
\hline & \multirow{2}{*}{ Density (plants $/ \mathrm{m}^{2}$ ) } & FG & $24.33 \pm 2.23^{b}$ & $0.44 \pm 0.34^{\mathrm{b}}$ & $73.44 \pm 34.95$ \\
\hline & & GE & $44.56 \pm 7.08^{\mathrm{a}}$ & $14.22 \pm 2.24^{\mathrm{a}}$ & - \\
\hline & \multirow{2}{*}{ Importance value } & FG & $0.76 \pm 0.05^{\mathrm{b}}$ & $0.01 \pm 0.01^{\mathrm{b}}$ & $0.21 \pm 0.05$ \\
\hline & & GE & $0.91 \pm 0.03^{\mathrm{a}}$ & $0.09 \pm 0.03^{\mathrm{a}}$ & - \\
\hline
\end{tabular}

Note: Different lowercase letters mean significant difference between FG and GE plots at $P<0.05$ level. -, no value. Mean \pm SE.

\subsection{Aboveground and belowground biomasses}

Grassland productivity was described using $\mathrm{AGB}$ and BGB in this study. GE significantly increased AGB in both MNS and HTB $(P<0.05$; Table 4). However, the responses of BGB to GE 
in MNS and HTB were inconsistent $(P>0.05)$. In MNS, the biomasses of stems, leaves and inflorescences, and litter in the GE plot were increased by $56.6 \%, 71.3 \%$, and $147.9 \%$, respectively, compared with the FG plot, whereas they increased by $488.3 \%, 206.7 \%$, and $69.2 \%$ in HTB, respectively. Additionally, the root/shoot ratio significantly decreased by $57.7 \%$ in MNS and $77.4 \%$ in HTB after GE $(P<0.05)$.

Table 4 Biomass characteristics of desert plant community in the FG and GE plots in MNS and HTB

\begin{tabular}{|c|c|c|c|c|c|c|c|}
\hline \multirow{2}{*}{$\begin{array}{l}\text { Experimental } \\
\text { site }\end{array}$} & \multirow[b]{2}{*}{ Plot } & \multicolumn{5}{|c|}{ Biomass $\left(\mathrm{g} / \mathrm{m}^{2}\right)$} & \multirow{2}{*}{$\begin{array}{l}\text { Root } / \text { shoot } \\
\text { ratio }\end{array}$} \\
\hline & & Stem & $\begin{array}{c}\text { Leaves and } \\
\text { inflorescences }\end{array}$ & Litter & $\begin{array}{l}\text { Aboveground } \\
\text { parts }\end{array}$ & $\begin{array}{l}\text { Belowground } \\
\text { parts }\end{array}$ & \\
\hline \multirow{2}{*}{ MNS } & FG & $96.0 \pm 12.7^{\mathrm{b}}$ & $41.0 \pm 5.3^{\mathrm{b}}$ & $12.0 \pm 3.0^{\mathrm{b}}$ & $147.6 \pm 17.0^{\mathrm{b}}$ & $1497.7 \pm 457.2^{\mathrm{a}}$ & $13.8 \pm 2.1^{\mathrm{a}}$ \\
\hline & GE & $150.3 \pm 9.4^{\mathrm{a}}$ & $70.2 \pm 5.7^{\mathrm{a}}$ & $29.8 \pm 16.1^{\mathrm{a}}$ & $247.0 \pm 15.8^{\mathrm{a}}$ & $1847.7 \pm 138.0^{\mathrm{a}}$ & $5.8 \pm 1.8^{\mathrm{b}}$ \\
\hline \multirow{2}{*}{ HTB } & $\mathrm{FG}$ & $41.7 \pm 3.1^{\mathrm{b}}$ & $29.7 \pm 1.5^{b}$ & $11.6 \pm 2.8^{\mathrm{b}}$ & $81.8 \pm 4.6^{b}$ & $718.2 \pm 69.6^{\mathrm{a}}$ & $9.6 \pm 0.5^{\mathrm{a}}$ \\
\hline & GE & $245.4 \pm 28.4^{\mathrm{a}}$ & $91.1 \pm 9.0^{\mathrm{a}}$ & $19.7 \pm 1.8^{\mathrm{a}}$ & $356.2 \pm 37.4^{\mathrm{a}}$ & $685.6 \pm 7.7^{\mathrm{a}}$ & $2.2 \pm 0.3^{\mathrm{b}}$ \\
\hline
\end{tabular}

Note: Different lowercase letters mean significant difference between FG and GE plots at $P<0.05$ level. Mean \pm SE.

\subsection{Plant $\mathrm{C}$ and $\mathrm{N}$ storage}

As shown in Figures 1a and b, the biomass $\mathrm{C}$ storage of aboveground parts after GE significantly increased in MNS $(P<0.05)$, while the biomass $\mathrm{C}$ storage of belowground parts decreased after GE but the difference was not significant $(P>0.05)$. A large proportion of the total plant $\mathrm{C}$ storage was maintained in the belowground parts in both FG and GE plots $(86.3 \%$ and $75.8 \%$, respectively). The $\mathrm{C}$ storage of stems, leaves and inflorescences, and litter in the whole desert plant community respectively accounted for $15.0 \%, 6.8 \%$, and $2.5 \%$ of the total plant $\mathrm{C}$ storage in the GE plot and $9.2 \%, 3.7 \%$, and $0.8 \%$ of the total plant $\mathrm{C}$ storage in the FG plot (Fig. 1a).
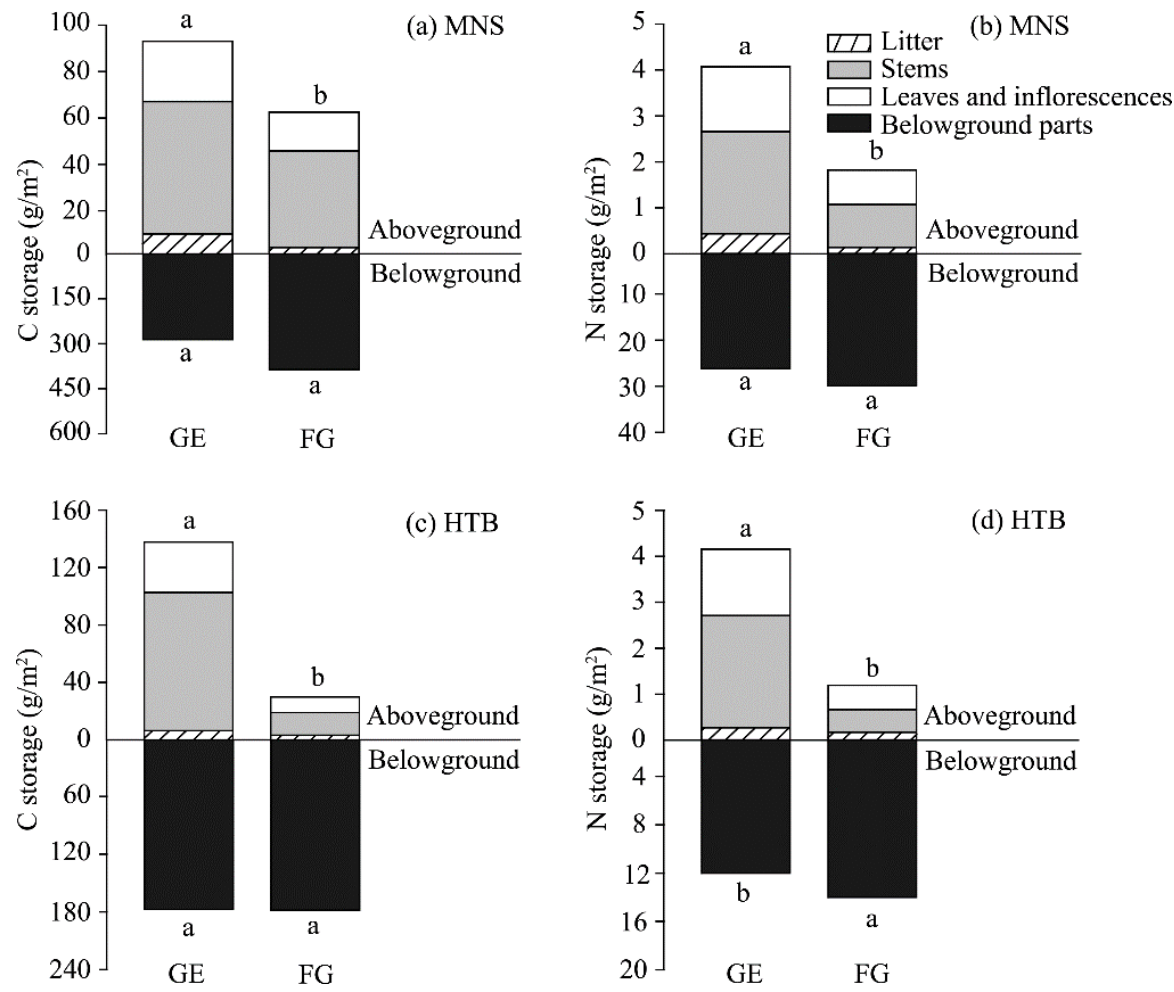

Fig. 1 Biomass carbon (C) and nitrogen (N) storage of aboveground and belowground parts of desert plant community in the FG and GE plots in MNS (a and b) and HTB (c and d). FG, freely grazing; GE, grazing exclusion; MNS, experiment site in the sagebrush desert region of Manas County; HTB, experiment site in the sagebrush desert region of Hutubi County. Different lowercase letters mean significant difference between FG and GE plots at $P<0.05$ level. 
Additionally, GE significantly increased the biomass N storage of aboveground parts in MNS, whereas there was a slight non-significant decrease in the biomass $\mathrm{N}$ storage of belowground parts after GE (Fig. 1b). The $\mathrm{N}$ storage of stems, leaves and inflorescences, litter and belowground parts of desert plant community respectively accounted for $7.4 \%, 4.7 \%, 1.4 \%$ and $86.5 \%$ of the total $\mathrm{N}$ storage in the GE plot and $2.9 \%, 2.4 \%, 0.4 \%$ and $94.3 \%$ of the total $\mathrm{N}$ storage in the FG plot (Fig. 1b).

In HTB, the biomass $\mathrm{C}$ and $\mathrm{N}$ storage levels of aboveground parts in the GE plots were significantly higher (4.61 and 3.49 times, respectively) than those in the FG plots $(P<0.05$; Figs. 1c and $\mathrm{d}$ ). There was a slight but non-significant decrease in the biomass $\mathrm{C}$ storage of belowground parts after GE, while the biomass $\mathrm{N}$ storage of belowground parts significantly decreased $(P<0.05$; Fig. 1d). The biomass $\mathrm{C}$ storage of belowground parts in the GE and FG plots accounted for the majority of the total plant $\mathrm{C}$ storage $(56.3 \%$ and $85.6 \%$, respectively) in HTB. After GE, the C storage proportions of stems, leaves and inflorescences, and litter of desert plant community changed from $7.6 \%$ to $30.5 \%, 5.2 \%$ to $11.2 \%$, and $1.6 \%$ to $2.0 \%$, respectively (Fig. 1c). The $\mathrm{N}$ storage allocations in different parts of plant were similar to the trends in $\mathrm{C}$ storage allocations.

\subsection{Concentration and storage of SOC and STN}

SOC and STN concentrations in different soil layers in the FG and GE plots in MNS and HTB are shown in Figure 2. GE did not significantly change the SOC concentration in any of the tested soil layers in both MNS and HTB ( $P>0.05$; Figs. 2a and c). However, compared to the FG plots, the STN concentration in the $0-5$ and $5-10 \mathrm{~cm}$ soil layers was significantly reduced by $34.5 \%$ and $24.4 \%$, respectively, after GE in MNS ( $P<0.05$; Fig. 2 b), and reduced by $36.8 \%$ and $37.2 \%$, respectively, after GE in $\mathrm{HTB}(P<0.05$; Fig. $2 \mathrm{~d})$. Additionally, the soil $\mathrm{C} / \mathrm{N}$ ratio was not significantly different between GE and FG plots in both MNS and HTB ( $P>0.05$; Fig. 3$)$.

In MNS, the responses of SOC and STN storage to GE in the topsoil layer $(0-10 \mathrm{~cm})$ were low $(P>0.05$; Table 5). The SOC storage in the $0-5$ and $5-10 \mathrm{~cm}$ soil layers were reduced by $23.4 \%$ and $7.6 \%$ after GE, respectively, and the STN storage was reduced by $31.9 \%$ and $26.0 \%$, respectively. There was no significant difference in the SOC or STN storage of the whole 0-100 $\mathrm{cm}$ soil layer $(P>0.05)$. Additionally, in HTB, the SOC and STN storage in the $0-5 \mathrm{~cm}$ soil layer after GE decreased by $8.2 \%$ and $43.3 \%$, respectively, and the SOC and STN storage in the whole $0-100 \mathrm{~cm}$ soil layer also slightly decreased by $17.9 \%$ and $34.8 \%(P>0.05)$, respectively.
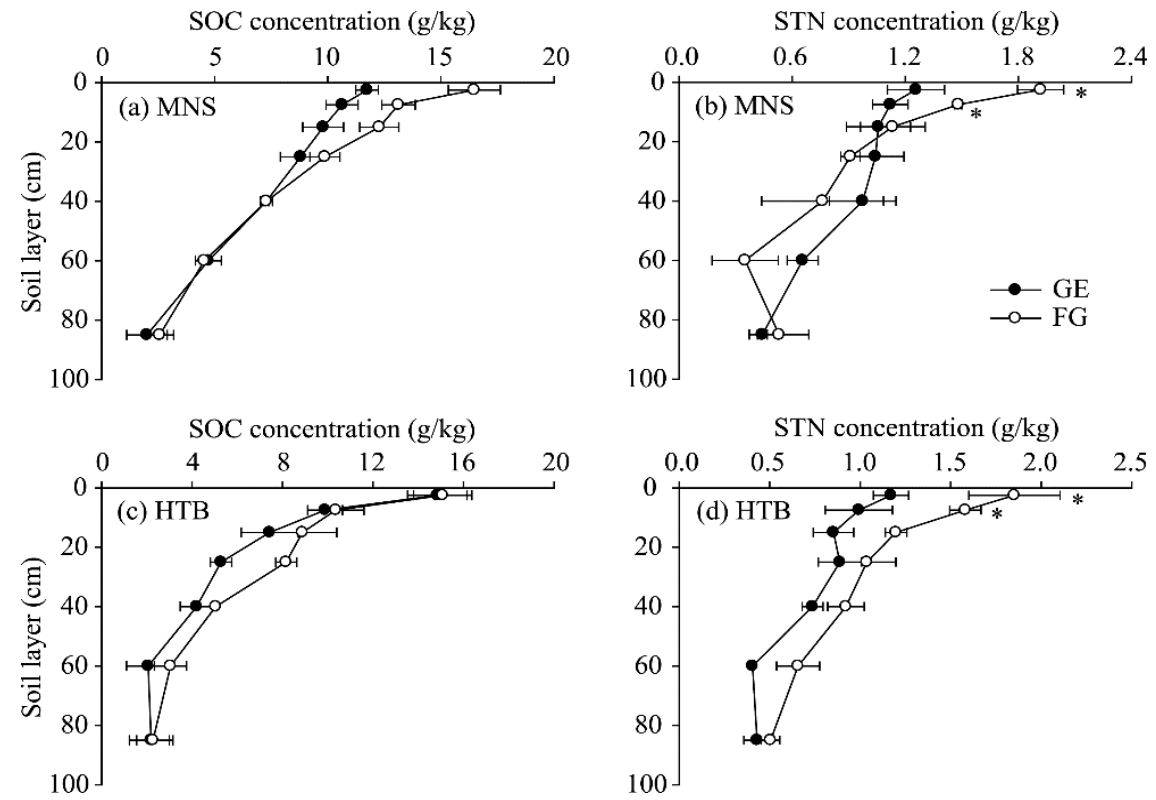

Fig. 2 Soil organic carbon (SOC) and soil total nitrogen (STN) concentrations in different soil layers in the FG and GE plots in MNS (a and b) and HTB (c and d). ${ }^{*}$ means significant difference among different soil layers at $P<0.05$ level. Error bar means standard error. 
(a) MNS

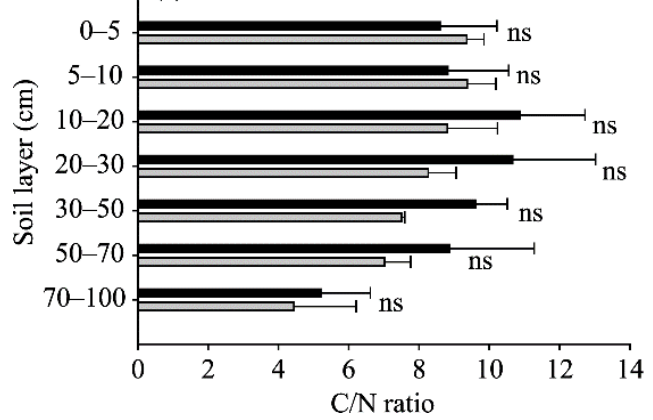

(b) HTB

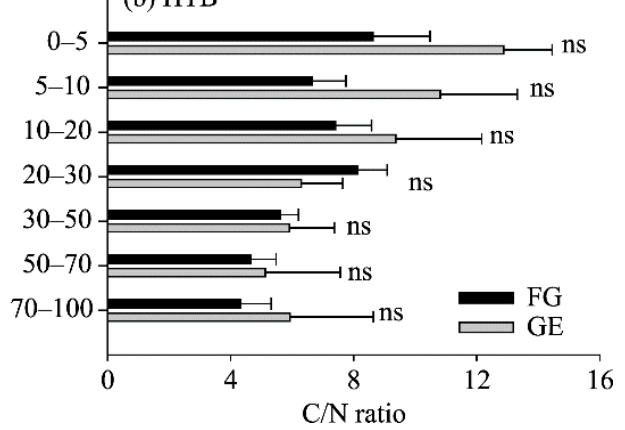

Fig. 3 Soil $\mathrm{C} / \mathrm{N}$ ratios in different soil layers in the FG and GE plots in MNS (a) and HTB (b). ns means significant difference among different soil layers at $P<0.05$ level. Error bar means standard error.

Table 5 Soil $\mathrm{C}$ and $\mathrm{N}$ storage in different soil layers in the FG and GE plots in MNS and HTB

\begin{tabular}{|c|c|c|c|c|c|}
\hline \multirow{2}{*}{$\begin{array}{l}\text { Experimental } \\
\text { site }\end{array}$} & \multirow{2}{*}{$\begin{array}{l}\text { Soil layer } \\
(\mathrm{cm})\end{array}$} & \multicolumn{2}{|c|}{ Soil C storage $\left(\mathrm{g} / \mathrm{m}^{2}\right)$} & \multicolumn{2}{|c|}{ Soil N storage $\left(\mathrm{g} / \mathrm{m}^{2}\right)$} \\
\hline & & FG & GE & FG & GE \\
\hline \multirow[t]{8}{*}{ MNS } & $0-5$ & $6641.5 \pm 1778.6^{\mathrm{a}}$ & $5088.1 \pm 1768.3^{\mathrm{a}}$ & $804.9 \pm 190.7^{\mathrm{a}}$ & $548.1 \pm 190.7^{\mathrm{a}}$ \\
\hline & $5-10$ & $3551.1 \pm 948.6^{\mathrm{a}}$ & $3281.4 \pm 1417.7^{\mathrm{a}}$ & $445.4 \pm 138.4^{\mathrm{a}}$ & $329.4 \pm 126.5^{\mathrm{a}}$ \\
\hline & $10-20$ & $5810.3 \pm 2118.5^{\mathrm{a}}$ & $6019.1 \pm 3348.5^{\mathrm{a}}$ & $542.9 \pm 155.3^{\mathrm{a}}$ & $590.2 \pm 292.5^{\mathrm{a}}$ \\
\hline & $20-30$ & $2937.7 \pm 904.1^{\mathrm{a}}$ & $2275.9 \pm 959.0^{\mathrm{a}}$ & $268.4 \pm 47.7^{\mathrm{a}}$ & $269.9 \pm 101.0^{\mathrm{a}}$ \\
\hline & $30-50$ & $3580.2 \pm 1438.1^{\mathrm{a}}$ & $5944.5 \pm 478.5^{\mathrm{a}}$ & $407.7 \pm 196.7^{\mathrm{a}}$ & $797.2 \pm 641.3^{\mathrm{a}}$ \\
\hline & $50-70$ & $1600.6 \pm 388.9^{\mathrm{a}}$ & $1696.1 \pm 1122.1^{\mathrm{a}}$ & $164.7 \pm 99.5^{\mathrm{a}}$ & $215.3 \pm 125.7^{\mathrm{a}}$ \\
\hline & $70-100$ & $814.9 \pm 266.0^{\mathrm{a}}$ & $329.9 \pm 221.4^{\mathrm{a}}$ & $161.9 \pm 57.2^{\mathrm{a}}$ & $67.2 \pm 22.6^{\mathrm{a}}$ \\
\hline & $0-100$ & $24,936.4 \pm 6540.4^{\mathrm{a}}$ & $24,635.1 \pm 1,3029.2^{\mathrm{a}}$ & $2795.8 \pm 645.9^{\mathrm{a}}$ & $2817.4 \pm 1386.1^{\mathrm{a}}$ \\
\hline \multirow[t]{8}{*}{ НТВ } & $0-5$ & $3501.6 \pm 283.3^{\mathrm{a}}$ & $3213.9 \pm 1465.7^{\mathrm{a}}$ & $446.1 \pm 101.4^{\mathrm{a}}$ & $253.0 \pm 105.6^{\mathrm{a}}$ \\
\hline & $5-10$ & $1267.8 \pm 48.9^{\mathrm{a}}$ & $1861.4 \pm 593.1^{\mathrm{a}}$ & $199.8 \pm 28.5^{\mathrm{a}}$ & $219.7 \pm 118.3^{\mathrm{a}}$ \\
\hline & $10-20$ & $2239.0 \pm 604.4^{\mathrm{a}}$ & $1616.7 \pm 310.5^{\mathrm{a}}$ & $291.8 \pm 34.6^{\mathrm{a}}$ & $182.9 \pm 17.5^{\mathrm{b}}$ \\
\hline & $20-30$ & $1174.3 \pm 284.6^{\mathrm{a}}$ & $573.3 \pm 179.7^{\mathrm{a}}$ & $143.0 \pm 29.5^{\mathrm{a}}$ & $95.3 \pm 18.3^{\mathrm{a}}$ \\
\hline & $30-50$ & $1378.5 \pm 312.0^{\mathrm{a}}$ & $886.0 \pm 180.3^{\mathrm{a}}$ & $241.4 \pm 44.0^{\mathrm{a}}$ & $152.9 \pm 7.1^{\mathrm{a}}$ \\
\hline & $50-70$ & $666.8 \pm 241.3^{\mathrm{a}}$ & $329.2 \pm 161.8^{\mathrm{a}}$ & $144.4 \pm 55.7^{\mathrm{a}}$ & $63.4 \pm 22.5^{\mathrm{a}}$ \\
\hline & $70-100$ & $627.6 \pm 330.2^{\mathrm{a}}$ & $429.5 \pm 242.2^{\mathrm{a}}$ & $125.6 \pm 43.6^{\mathrm{a}}$ & $70.7 \pm 20.6^{\mathrm{a}}$ \\
\hline & $0-100$ & $10,855.8 \pm 1310.3^{\mathrm{a}}$ & $8910.1 \pm 1336.2^{\mathrm{a}}$ & $1592.2 \pm 71.4^{\mathrm{a}}$ & $1037.9 \pm 72.0^{\mathrm{b}}$ \\
\hline
\end{tabular}

Note: C, carbon; N, nitrogen. Different lowercase letters mean significant difference between FG and GE plots at $P<0.05$ level.

\section{Discussion}

\subsection{Responses of desert plant community structure to GE}

The response of vegetation community structure and characteristics to GE is variable in different grassland ecosystems (Guo, 2007; Marriott et al., 2009). The average height and total coverage of plant species are important factors used to evaluate the health of the grasslands (Xiong et al., 2014). The present study showed that three years of GE can have a significant positive effect on the height and coverage of desert plants in the two sites (MNS and HTB; Table 2), a result which is supported by previous studies in other grassland types (Jing et al., 2014; Wang et al., 2016; Bi et al., 2018; Fu et al., 2018). One reasonable explanation for this result is that frequent heavy grazing or overgrazing inhibits the growth of the dominant species (Seriphidium transiliense) due to both the feeding and trampling of livestock, and that GE benefits the regeneration both of plant species and soil seed bank, enhancing the ability of grasslands to recover (Wang et al., 2016). Additionally, GE can alter the species composition due to selective grazing by livestock (Golodets et al., 2010). In our study, GE increased the average height, coverage and importance values of subshrubs and perennial herbs, whereas it decreased those values amongst annual herbs 
(Table 3). Most of subshrubs (e.g., Seriphidium transiliense and Kochia prostrata) and perennial herbs (e.g., Carex turkestanica) are palatable. They were prioritized by livestock for consumption and then regenerated after GE (Bi et al., 2018). The previously suppressed species rapidly increased and occupied a large amount of light and space resources, thus restraining the less competitive annuals. Another interpretation of the mechanism is that $C$. turkestanica is a perennial grass that can be reproduced by rhizomes, which is a mechanism that is favored over the sexual reproduction of other species on the removal of grazing pressures.

GE had positive or non-significant effects on richness, diversity and evenness indices in the two sites (Table 2). Yayneshet et al. (2009) reported similar findings from semi-arid, grass-wood mixed grasslands after GE of more than five years, and their study showed that species diversity increased compared to grazed land. However, some opposite findings were reported in other similar studies (Wu et al., 2009). The findings were related to the promotion of plants' ability to reproduce by removing the disturbance from livestock (Sternberg et al., 2000). Palatable grasses had greater competitiveness than unpalatable species after GE (Gallego et al., 2004). Therefore, GE promoted the growth of suppressed species, which may explain why it enhanced species richness in deserts, mountain meadows (Bi et al., 2018) and alpine grasslands (Wu et al., 2010).

\subsection{Responses of desert plant productivity to GE}

Biomass is often regarded as a good approximation of grassland productivity (Yan and Lu, 2015). GE significantly enhanced the AGB of desert plant community in the two experimental sites (Table 4). AGB increased markedly in the GE plots, mainly due to the absence of feeding and trampling by livestock (Schönbach et al., 2011; Deng et al., 2014a; Dong et al., 2017). In the FG plots, the continuous removal of stems, leaves and inflorescences by livestock results in the degradation of aboveground parts, including the standing and litter biomass (Schönbach et al., 2011).

Nevertheless, there are controversies in previous work on the effects of GE on BGB. Some studies showed that GE with fencing increased the BGB (Deng et al., 2014b; Cheng et al., 2016) due to grazing removed plant tissues and thus decreased the size of carbon-assimilating organs (Gao et al., 2009). Others have observed that the response of BGB to GE showed no change or even a significant decrease (Wang et al., 2016; Bi et al., 2018). One reasonable explanation is that plants adapt to grazing by decreasing the energy outflow from AGB to herbivores, actively directing more assimilation to BGB as a storage for regeneration (Hafner et al., 2012). Consequently, the BGB is lower in the GE plots than in the FG plots. In the present study, GE did not obviously alter the BGB in either MNS or HTB $(P>0.05$; Table 4$)$. The reason for the conflicting findings in previous cases likely relates to differences in environmental conditions, grassland types, duration of GE and other factors (Luan et al., 2014; Shen et al., 2016; Xiong et al., 2016).

\subsection{Effects of GE on plant $C$ and $N$ storage}

Plant C and N storage levels are dependent on AGB and BGB (Wang et al., 2016). In this study, we found that the biomass $\mathrm{C}$ and $\mathrm{N}$ storage levels of aboveground parts after three years of GE in MNS and HTB were higher than those in the FG plots $(P<0.05$; Fig. 1). Wang et al. (2014) also indicated that GE enhanced the $\mathrm{C}$ and $\mathrm{N}$ storage of AGB after eight years of GE. One possible explanation is that the recovery and regeneration of vegetation after GE increase the vegetation $\mathrm{C}$ and $\mathrm{N}$ storage, which is consistent with other experiments (Wu et al., 2010; Bi et al., 2018). In the present study, the biomass $\mathrm{C}$ and $\mathrm{N}$ storage levels of belowground parts were reduced or showed no change in the GE plots compared to those in the FG plots (Fig. 1). The results were consistent with other studies (Qiu et al., 2013; Deng et al., 2014b). Additionally, the C and N pools in the belowground parts of plant in both MNS and HTB were larger than those in the aboveground parts. The pattern was related to the high decomposability of shoot material (stems, leaves and inflorescences) compared to roots (Dodd and Mackay, 2011). As a result, BGB has been seen as vital for $\mathrm{C}$ and $\mathrm{N}$ belowground sinks (Wu et al., 2010). 


\subsection{Effects of GE on SOC and STN storage}

In our research, GE can be summarized as playing an opposite role in preserving soil $\mathrm{C}$ in both MNS and HTB, especially on the surface soil layer (Fig. 2; Table 5). Nevertheless, there have been inconsistent findings in previous literature with regard to GE. Nosetto et al. (2006) observed that 15 years of GE did not increase the SOC storage compared to grazed land. Some other studies also supported the results (Shrestha and Stahl, 2008; Medinaroldán et al., 2012) revealed by our study. Our results suggested that the amount of SOC stored in the soil represents the net balance between the loss and input in SOC pools (Post and Kwon, 2000), although the SOC concentration and storage slightly increased in most soil layers. However, most results in the research literature demonstrated that GE significantly enhanced the SOC sequestration (e.g., Pei et al., 2008; Hu et al., 2016). Pei et al. (2008), for example, indicated that the SOC clearly increased in the 0-20 cm soil layer after only two years of GE due to the removal of livestock disturbance. If the grazing intensity exceeds the carrying capacity of grasslands or crosses an ecological threshold, the SOC can be significantly altered after GE (Sasaki et al., 2011). The inconsistency of these findings is likely related to complicating factors, such as the GE duration, the initial soil conditions, the grassland types, the regional climate and environmental conditions, the community structure of the grasslands and the degree of degradation before GE (Li et al., 2015; Shen et al., 2016).

In this study, GE affected soil $\mathrm{N}$ concentration and storage in a manner similar to soil $\mathrm{C}$ concentration and storage in most soil layers in the sagebrush desert. However, GE significantly decreased soil $\mathrm{N}$ concentration in the $0-10 \mathrm{~cm}$ soil layer and soil $\mathrm{N}$ storage in the whole $0-100$ $\mathrm{cm}$ soil layer in HTB. Shi et al. (2013) indicated that on the Tibetan Plateau, soil N storage decreased after GE, which is consistent with our results. However, GE increased soil N storage in the three headwater resource regions of Tibetan Plateau (Fan et al., 2013). The inconsistency may result from the balance between changes in $\mathrm{N}$ allocation (the $\mathrm{N}$ retention hypothesis) and the ability of soil to maintain the $\mathrm{N}$ available after GE (the loss hypothesis) (Piñeiro et al., 2009, 2010). Additionally, the soil $\mathrm{C} / \mathrm{N}$ ratio was not significantly different between GE and $\mathrm{FG}$ plots in both MNS and HTB $(P>0.05)$, which indicates a close coupling between soil $\mathrm{C}$ and $\mathrm{N}$ (Deng et al., 2014b; Wang et al., 2016).

\section{Conclusions}

The objective of the current study was to understand the effectiveness of short-term GE (three years) in restoring degraded sagebrush desert in Northwest China. We investigated mainly the community structure, plant biomass, and $\mathrm{C}$ and $\mathrm{N}$ storage of plants and soil $(0-100 \mathrm{~cm}$ depth) in the GE plots and adjacent FG plots. Our findings suggested that GE significantly increased the average height and total coverage of desert plant community, and the height, coverage and importance values of subshrubs and perennial herbs. However, it decreased the importance values of annual herbs. GE is conducive to the maintenance of plant species diversity, as measured by the richness, diversity and evenness indices. Another important finding was that GE altered the biomass allocation. It increased the proportion of stems, leaves and inflorescences, and litter in the GE plots, but decreased the root/shoot ratio, and produced no clear change of AGB. Similarly, GE can increase the biomass $\mathrm{C}$ and $\mathrm{N}$ storage of aboveground parts, but did not promote the $\mathrm{C}$ and $\mathrm{N}$ storage in belowground parts of plants and soil, especially the topsoil layer $(0-10 \mathrm{~cm})$. In general, GE can effectively help recover the degraded desert grassland, and reverse the trend of vegetation degradation. The study provides a basis for sustainable management strategies of vegetation in the sagebrush desert in the arid regions.

\section{Acknowledgements}

This work was supported by the National Basic Resources Survey Project of China (2017FY100201), and the Grassology Peak Discipline Foundation of Xinjiang Uygur Autonomous Region, China (CXGFXK-2019-01). 


\section{References}

Bao S D. 2000. Soil and Agricultural Chemistry Analysis ( $3^{\text {rd }}$ ed.). Beijing: China Agriculture Press, 263-270. (in Chinese)

Bi X, Li B, Fu Q, et al. 2018. Effects of grazing exclusion on the grassland ecosystems of mountain meadows and temperate typical steppe in a mountain-basin system in Central Asia's arid regions, China. Science of the Total Environment, 630: 254263.

Cheng J M, Jing G H, Wei L, et al. 2016. Long-term grazing exclusion effects on vegetation characteristics, soil properties and bacterial communities in the semi-arid grasslands of China. Ecological Engineering, 97: 170-178.

Deng L, Sweeney S, Shangguan Z P. 2014a. Long-term effects of natural enclosure: Carbon stocks, sequestration rates and potential for grassland ecosystems in the Loess Plateau. Clean-Soil, Air, Water, 42(5): 617-625.

Deng L, Zhang Z, Shangguan Z P. 2014b. Long-term fencing effects on plant diversity and soil properties in China. Soil and Tillage Research, 137(1): 7-15.

Dodd M B, Mackay A D. 2011. Effects of contrasting soil fertility on root mass, root growth, root decomposition and soil carbon under a New Zealand perennial ryegrass/white clover pasture. Plant and Soil, 349(1-2): 291-302.

Dong S K, Wen L, Liu S L, et al. 2011. Vulnerability of worldwide pastoralism to global changes and interdisciplinary strategies for sustainable pastoralism. Ecology and Society, 16(2): 85-99.

Dong S K, Wen L, Li Y Y, et al. 2012. Soil-quality effects of grassland degradation and restoration on the Qinghai-Tibetan Plateau. Soil Science Society of America Journal, 76(6): 2256-2264.

Dong Y Q, Sun Z J, An S Z, et al. 2016. Effect of grazing intensity on population characteristics and community diversity of Seriphidium transiliense. Acta Agrestia Sinica, 24(1): 22-24. (in Chinese)

Dong Y Q, Sun Z J, An S Z, et al. 2017. Natural restoration of degraded grassland on the northern Xinjiang, China: The restoration difference between lightly and moderately degraded deserts under grazing exclusion. Fresenius Environmental Bulletin, 26(6): 3845-3855.

Ebrahimi M, Khosravi H, Rigi M. 2016. Short-term grazing exclusion from heavy livestock rangelands affects vegetation cover and soil properties in natural ecosystems of southeastern Iran. Ecological Engineering, 95: 10-18.

El-Keblawy A. 2017. Impact of fencing and irrigation on species composition and diversity of desert plant communities in the United Arab Emirates. Land Degradation \& Development, 28(4): 1354-1362.

Fan Y J, Hou X Y, Shi H X. 2013. Effects of grazing and fencing on carbon and nitrogen reserves in plants and soils of alpine meadow in the three headwater resource regions. Russian Journal of Ecology, 44(1): 80-88.

Fang J Y, Guo Z D, Piao S L, et al. 2007. Terrestrial vegetation carbon sinks in China, 1981-2000. Science in China Series D: Earth Sciences, 50(9): 1341-1350. (in Chinese)

Feng R Z, Long R J, Shang Z H, et al. 2010. Establishment of Elymus natans improves soil quality of a heavily degraded alpine meadow in Qinghai-Tibetan Plateau, China. Plant and Soil, 327(1-2): 403-411.

Fu G, Zhang X Z, Yu C Q, et al. 2014. Response of soil respiration to grazing in an alpine meadow at three elevations in Tibet. Scientific World Journal, 2014: 265142, doi: 10.1155/2014/265142.

Fu G, Shen Z X. 2017. Clipping has stronger effects on plant production than does warming in three alpine meadow sites on the Northern Tibetan Plateau. Scientific Reports, 7(1): 16330, doi: 10.1038/s41598-017-16645-2.

Fu G, Shen Z X, Zhang X Z. 2018. Increased precipitation has stronger effects on plant production of an alpine meadow than does experimental warming in the northern Tibetan Plateau. Agricultural and Forest Meteorology, 249: 11-21.

Gallego L, Distel R A, Camina R. 2004. Soil phytoliths as evidence for species replacement in grazed rangelands of central Argentina. Ecography, 27(6): 725-732.

Gao Y H, Schumann M, Chen H, et al. 2009. Impacts of grazing intensity on soil carbon and nitrogen in an alpine meadow on the eastern Tibetan Plateau. Journal of Food, Agriculture \& Environment, 7(2): 749-754.

Golodets C, Kigel J, Sternberg M. 2010. Recovery of plant species composition and ecosystem function after cessation of grazing in a Mediterranean grassland. Plant and Soil, 329(1-2): 365-378.

Guo Q F. 2007. The diversity-biomass-productivity relationships in grassland management and restoration. Basic and Applied Ecology, 8(3): 199-208.

Hafner S, Unteregelsbacher S, Seeber E, et al. 2012. Effect of grazing on carbon stocks and assimilate partitioning in a Tibetan montane pasture revealed by ${ }^{13} \mathrm{CO}_{2}$ pulse labeling. Global Change Biology, 18(2): 528-538.

Hu Z M, Li S G, Guo Q, et al. 2016. A synthesis of the effect of grazing exclusion on carbon dynamics in grasslands in China. Global Change Biology, 22(4): 1385-1393.

Jing Z B, Cheng J M, Su J H, et al. 2014. Changes in plant community composition and soil properties under 3-decade grazing exclusion in semiarid grassland. Ecological Engineering, 64(3): 171-178. 
Li Q, Zhou D W, Jin Y H, et al. 2014. Effects of fencing on vegetation and soil restoration in a degraded alkaline grassland in Northeast China. Journal of Arid Land, 6(4): 478-487.

Li Y Q, Zhao X Y, Zhang F X, et al. 2015. Accumulation of soil organic carbon during natural restoration of desertified grassland in China's Horqin Sandy Land. Journal of Arid Land, 7(3): 328-340.

Lu X Y, Yan Y, Jian S, et al. 2015. Carbon, nitrogen, and phosphorus storage in alpine grassland ecosystems of Tibet: Effects of grazing exclusion. Ecology \& Evolution, 5(19): 4492-4504.

Luan J W, Cui L J, Xiang C H, et al. 2014. Different grazing removal exclosures effects on soil C stocks among alpine ecosystems in east Qinghai-Tibet Plateau. Ecological Engineering, 64(3): 262-268.

Marriott C A, Hood K, Fisher J M, et al. 2009. Long-term impacts of extensive grazing and abandonment on the species composition, richness, diversity and productivity of agricultural grassland. Agriculture, Ecosystem and Environment, 134(34): 190-200.

Mcsherry M E, Ritchie M E. 2013. Effects of grazing on grassland soil carbon: A global review. Global Change Biology, 19(5): $1347-1357$.

Medinaroldán E, Pazferreiro J, Bardgett R D. 2012. Grazing exclusion affects soil and plant communities, but has no impact on soil carbon storage in an upland grassland. Agriculture Ecosystems \& Environment, 149: 118-123.

Mekuria W, Aynekulu E. 2013. Exclosure land management for restoration of the soils in degrade communal grazing lands in northern Ethiopia. Land Degradation and Development, 24(6): 528-538.

Nosetto M D, Jobbágy E G, Paruelo J M. 2006. Carbon sequestration in semi-arid rangelands: Comparison of Pinus ponderosa plantations and grazing exclusion in NW Patagonia. Journal of Arid Environments, 67(1): 142-156.

Pei S F, Fu H, Wan C G. 2008. Changes in soil properties and vegetation following exclosure and grazing in degraded Alxa desert steppe of Inner Mongolia, China. Agriculture Ecosystems \& Environment, 124(1-2): 33-39.

Piñeiro G, Paruelo J M, Jobbágy E G, et al. 2009. Grazing effects on belowground C and N stocks along a network of cattle exclosures in temperate and subtropical grasslands of South America. Global Biogeochemical Cycles, 23(2): GB2003, doi: $10.1029 / 2007 \mathrm{~GB} 003168$.

Piñeiro G, Paruelo J M, Oesterheld M. 2010. Potential long-term impacts of livestock introduction on carbon and nitrogen cycling in grasslands of southern South America. Global Change Biology, 12(7): 1267-1284.

Post W M, Kwon K C. 2010. Soil carbon sequestration and land-use change: Processes and potential. Global Change Biology, 6(3): 317-327.

Qiu L P, Wei X R, Zhang X C, et al. 2013. Ecosystem carbon and nitrogen accumulation after grazing exclusion in semiarid grassland. PloS ONE, 8(1): e55433, doi: 10.1371/journal.pone.0055433.

Sasaki T, Okayasu T, Jamsran U, et al. 2011. Indicator species and functional groups as predictors of proximity to ecological thresholds in Mongolian rangelands. Plant Ecology, 212(2): 327-342.

Schönbach P, Wan H W, Gierus M. 2011. Grassland responses to grazing: Effects of grazing intensity and management system in an inner Mongolian steppe ecosystem. Plant and Soil, 340(1-2): 103-115.

Shao H Y, Sun X F, Wang H X, et al. 2016. A method to the impact assessment of the returning grazing land to grassland project on regional eco-environmental vulnerability. Environmental Impact Assessment Review, 56: 155-167.

Shen Z X, Zhou N, Fu G, et al. 2016. Comparison of community carbon and nitrogen contents under fencing and grazing in an alpine meadow at three elevations in the northern Tibet. Ecology and Environmental Sciences, 25(3): 372-376.

Shi X M, Li X G, Li C T, et al. 2013. Grazing exclusion decreases soil organic C storage at an alpine grassland of the Qinghai-Tibetan Plateau. Ecological Engineering, 57(3): 183-187.

Shi Y, Wang Y C, Ma Y M, et al. 2014. Field-based observations of regional-scale, temporal variation in net primary production in Tibetan alpine grasslands. Biogeosciences Discussions, 10(10): 16843-16878.

Shrestha G, Stahl P D. 2008. Carbon accumulation and storage in semi-arid sagebrush steppe: Effects of long-term grazing exclusion. Agriculture, Ecosystems \& Environment, 125(1-4): 173-181.

Sigcha F, Pallavicini Y, Camino M J, et al. 2018. Effects of short-term grazing exclusion on vegetation and soil in early succession of a subhumid Mediterranean reclaimed coal mine. Plant and Soil, 426(1-2): 197-209.

Sternberg M, Gutman M, Perevolotsky A, et al. 2000. Vegetation response to grazing management in a Mediterranean herbaceous community: A functional group approach. Journal of Applied Ecology, 37(2): 224-237.

Wang D, Wu G L, Zhu Y J, et al. 2014. Grazing exclusion effects on above- and below-ground C and N pools of typical grassland on the Loess Plateau (China). Catena, 123: 113-120.

Wang K B, Deng L, Ren Z P, et al. 2016. Grazing exclusion significantly improves grassland ecosystem C and N pools in a desert steppe of Northwest China. Catena, 137: 441-448.

Wang X, Yang X G, Wang L, et al. 2018. A six-year grazing exclusion changed plant species diversity of a Stipa breviflora 
desert steppe community, northern China. PeerJ, 6(6): e4359, doi: 10.7717/peerj.4359.

Wu G L, Du G Z, Liu Z H, et al. 2009. Effect of fencing and grazing on a Kobresia-dominated meadow in the Qinghai-Tibetan Plateau. Plant and Soil, 319(1-2): 115-126.

Wu G L, Liu Z H, Zhang L, et al. 2010. Long-term fencing improved soil properties and soil organic carbon storage in an alpine swamp meadow of western China. Plant and Soil, 332(1-2): 331-337.

Wu J S, Shen Z X, Shi P L, et al. 2014. Effects of grazing exclusion on plant functional group diversity of alpine grasslands along a precipitation gradient on the northern Tibetan Plateau. Arctic Antarctic and Alpine Research, 46(2): 419-429.

Wu X, Li Z S, Fu B J, et al. 2014a. Effects of grazing exclusion on soil carbon and nitrogen storage in semi-arid grassland in Inner Mongolia, China. Chinese Geographical Science, 24(4): 479-487.

Wu X, Li Z S, Fu B J, et al. 2014b. Restoration of ecosystem carbon and nitrogen storage and microbial biomass after grazing exclusion in semi-arid grasslands of Inner Mongolia. Ecological Engineering, 73(1): 395-403.

Xiong D P, Shi P L, Sun Y L, et al. 2014. Effects of grazing exclusion on plant productivity and soil carbon, nitrogen storage in alpine meadows in northern Tibet, China. Chinese Geographical Science, 24(4): 488-498.

Xiong D P, Shi P L, Zhang X Z, et al. 2016. Effects of grazing exclusion on carbon sequestration and plant diversity in grasslands of China: A meta-analysis. Ecological Engineering, 94: 647-655.

Yan Y, Lu X Y. 2015. Is grazing exclusion effective in restoring vegetation in degraded alpine grasslands in Tibet, China? PeerJ, 3(6): e1020, doi: 10.7717/peerj.1020.

Yayneshet T, Eik L O, Moe S R. 2009. The effects of exclosures in restoring degraded semi-arid vegetation in communal grazing lands in northern Ethiopia. Journal of Arid Environments, 73(4-5): 542-549.

Zhang X Z, Shen Z X, Fu G. 2015. A meta-analysis of the effects of experimental warming on soil carbon and nitrogen dynamics on the Tibetan Plateau. Applied Soil Ecology, 87: 32-38.

Zhang Y Y, Zhao W Z. 2015. Vegetation and soil property response of short-time fencing in temperate desert of the Hexi Corridor, northwestern China. Catena, 133: 43-51.

Zhao L P, Su J S, Wu G L, et al. 2011. Long-term effects of grazing exclusion on aboveground and belowground plant species diversity in a steppe of the Loess Plateau, China. Plant Ecology and Evolution, 144(3): 313-320. 